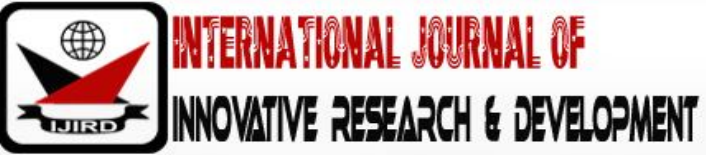

ISSN 2278 - 0211 (Online)

\section{Effects of Group Investigation Strategy on Secondary School Students' Academic Achievement in Biology in Kwali Educational Zone of FCT-Abuja}

F. U Ebele
Professor, Department of Science and Environmental Education,
University of Abuja, Nigeria
Zainab Abubakar
Assistant Lecturer, Department of Science and Environmental Education,
University of Abuja, Nigeria

\begin{abstract}
:
This study investigated the effects of Group Investigation Strategy on secondary school students' academic achievement in Biology in Kwali Educational Zone, FCT, Abuja. The research design used was quasi experimental using pre-test and post-test control group approach. Two research questions and two hypotheses were raised. The population of the study consisted of 2147 SS II Biology students, out of which 90 Biology students from the two selected senior secondary schools in Kwali Educational Zone, Abuja formed the sample size for the study. Forty-six (46) students were randomly assigned as experimental and forty-four (44) students as control group. The instruments used to collect data were 30item Biology Achievement Test (BAT). Descriptive statistics were used to answer the two research questions, while ttest was used to test the two hypotheses. The results of the analysis showed that; there was significant difference between the mean achievement scores of experimental group and control group. There was no significant difference between the mean achievement scores of male and female students in the experimental group. Based on this, it is concluded that Group Investigation Strategy has effects on students' academic and that it is not gender biased. Based on these findings, it is recommended among others that; regular seminars, workshops and conferences should be held for science teachers to acquaint them with the knowledge of Group Investigation Strategy and should be encouraged to use it in the classrooms.
\end{abstract}

Keywords: Group investigation strategy, conventional teaching method, science education, biology and academic achievement

\section{Introduction}

Science education is a powerful instrument for national development (Leghara and Mba, 2010). The impact of science education on national development is felt in several ways; as it provides humanity with knowledge about the environment, attitudes and values for social living, knowledge and skills to explore and transform resources, change in quality of life and improvement in economy (Udofia, 2010). The major goal of science education is to develop scientifically literate individuals that are concerned with high competence for rational thoughts and actions. Science as school subjects comprises Physics, Chemistry, Mathematics, Agriculture and Biology.

Biology is one of the core science subjects that senior secondary school students offer at the senior levels in the Nigerian secondary schools, it was introduced to students at this level as a preparatory ground for human development, where career abilities are groomed, potentials and talents are discovered and energized (FGN, 2004). It is also a requirement for higher learning in a number of science-related professional courses like medicine, agriculture and pharmacy.

As a natural science subject, Biology deals with the study of living organisms (plant and animal) including their structure, functioning, growth, origin, evolution, distribution and interrelationship growth, origin, evolution, distribution. It is a science of life that plays a vital role in the life of every human being and deals with the living world: How the world is structured, how it functions and what these functions are, how it develops, how living things came into existence, and how they react to one another and with their environment (Umar, 2011).

In spite of the importance and popularity of biology among Nigerian students, performance at senior secondary school level has been poor (Ahmed, 2008). The poor performance in sciences as indicated by various empirical studies (Betiku, 2001; NECO \& WAEC Chief Examiner's reports, 2005, 2007, 2008-2015) have attracted the concern of stakeholders including the researcher. Consequently, many factors have been identified as being responsible for the 
dwindling trend in the performance of students. These factors according to Olatoye and Adekoya (2009) include: Schoolteacher related characteristics, teaching methods \& social incentives and a host of others. Kareem (2003), Ahmed \& Abimbola (2011) \& Umar (2011) stated that, the poor teaching methods adopted by teachers at senior secondary school level in Nigeria have been identified as one of the major factors contributing to poor performance of students in biology. This indicates that if the afforested factors and others can be addressed, students could excel more in sciences generally and biology in particular.

The extent to which the knowledge of science is imparted to the learner is largely dependent on the type of teaching methods adopted by the teacher (Orji \& Ebele (2011). More so, the pedagogical strategies adopted by teachers in Nigerian classroom for teaching biology are dominated by conventional methods which in most cases are chalk and talk method (Orji, 2010). These teaching methods are the various ways used by teachers to create learning environment and to specify the nature of the activity in which teachers and the learners will be involved during learning-process. It is primarily, a description of learning objective oriented activities and the flow of information between the teacher and the learner(s).O'Banon (2002) categorized teaching method into two approaches; namely: teacher centred-approach and student-centred approach.

Teacher-centred approach includes all the teaching methods that see the teacher as possessor of knowledge and the controller of the learning environment. It does not encourage deeper student's involvement and students are the passive recipient of the information already acquired by the teacher. Therefore, since they are taught using this method, the students are not able to get aware of better knowledge in learning biology. Also, it does not facilitate the development of reasoning skills and processes in the students. These, among other reasons had not enhanced learning in students and thus had led to poor achievement among biology students in secondary schools.

The student-centred approach includes all the instructional methods that enable active participation of the learner in the learning process. The students are in control of their own learning and learning may be independent, collaborative, cooperative and competitive. The teacher may be engaged with the students in a classroom collectively, individually or in groups. Their involvement would include questioning, disciplining, guiding, validating, monitoring, motivating, encouraging, suggesting, modelling and clarifying (McKenzie, 2005). The student-centred method is in line with the National Policy on Education (FRN, 2013). Therefore, one of such effective students-centred approach that is capable of enhancing student's retention of biology concepts is Group Investigation Strategy.

Group Investigation Strategy is one of the cooperative learning methods that focus on the activities of the students to develop their beliefs, feelings and attitudes towards the topic at hand and for testing an inquiry through democratic discussions, observations sharing and listening to others in the group (Salviana \& David, 2017). The primary goal of GIS was to create conditions that allow students, in collaboration with their classmates, to participate in the steps of scientific method which will help in stimulating the students' desires to participate and be more successful if they had a greater desire to investigate.

Kagan and Kagan (2009) proposed four basic features of Group Investigation, they are: first, by investigation, the classroom becomes an "inquiring community," and each student is an investigator of the class topic or problem; second by interaction, the students interact in small groups throughout the stages of investigation; third by interpretation, students interpret findings from the information they gather from a variety of sources; and fourth by intrinsic motivation, students are intrinsically motivated by their active role in the task and their natural curiosity in the subject matter is awoken.

In planning and carrying out Group investigation strategy, student's progress through six stages and these stages can be compressed into a week or two depending on the scope of the topic under investigation and the skilfulness of the students and the teacher. During Group Investigation, students determined subtopics after the teacher's presentation of the main topic. The teacher formed a cooperative group of 4 or 5 depending on the number of students in the class. All group members help plan how to research their topic, then they divide the work among themselves, and each group carried out his/ her part of the investigation. The group then synthesizes and summarizes its work and presents their findings to the class after which the teacher and the students evaluate their presentations (Parchment, 2009).

Group Investigation is an organizational medium for encouraging and guiding student's involvement in learning. Students actively share in influencing the nature of events in their classroom. Also, by communicating freely and cooperating in planning and carrying out their chosen topic of investigation, they can achieve more than they would as individuals. By so doing, group investigation strategy harnesses student's individual interests and gives them even more control over their learning than other cooperative learning methods do (Sharan \& Tan, 2013).

Another variable to consider here is gender. Gender is a social construct that differentiate male from female based on the physical features. Many researchers (Okoro, 2011; Abdu-Raheem, 2012 \& Nneka, 2015) have shown gender to be of significant influence in an investigation of this nature, hence the inclusion of gender as an intervening variable in the study. Based on this background therefore, the present study is set to investigate the effects of Group Investigation Strategy on secondary school students' Academic Achievement in Biology in Kwali Educational Zone of FCT-Abuja.

\section{Statement of the Problem}

The persistent poor achievements of students in Biology as revealed by Betiku (2001) and WAEC Chief Examiner's reports (2010-2015) call for concern. The persistent poor achievements have led to series of public outcries. Prominent among such public outcries is as noted during the release of WASSCE and NECO, SSCE results of the 2011 academic year. The results of the WASSCE were tagged national shame. "One million failed SSCE; only 31\% passed with 5 credits including English Language and Mathematics" (Dike \& Adebayo, 2011). The implication of the result is that 472,906 (only 31\%) candidates out of the 1,540,250 candidates who sat for the examination would be qualified for admission into tertiary institutions. It further disclosed that the 31\% pass in 2011 was an improvement over 2010 results which was only $23 \%$ 
pass but in 2012, 2013, 2015, and 2016 the performance rose to $38.8 \%, 38.3 \%, 38.7 \%$ and $53 \%$ respectively. While in 2014 it declined to $31.3 \%$.This implies that 529,425 candidates representing 31.3\% obtained credits in 5 subject including English Language and Mathematics.

The problem has to a large extent, been attributed to ineffective teaching method employed by teachers especially the use of conventional method of teaching which is teacher-centred and has been found to be non-productive. The implication of this failure in education is that Nigeria may have shortage of manpower in science and technology related disciplines and this may affect Nigeria's vision to become one of the 20 industrialized nations in the world by year 2020 . Consequently, there is felt need to improve on the teaching and learning of Biology by exploring the use of some innovative learner centred methods like Group Investigation Strategy.

\section{Purpose of the Study}

The general purpose of the study is to investigate the effects of Group Investigation Strategy on secondary school students' Academic Achievement in Biology in Kwali Educational Zone of FCT-Abuja. Specifically, the objectives of the study were to:

- Find out the achievement level between students who are exposed to Group Investigation Strategy and their counterpart exposed to conventional method.

- Determine whether gender has any effect on students' academic achievement when exposed to Group Investigation Strategy.

\section{Research Questions}

The following research questions were raised to guide this study:

- What is the difference in students' achievement level in Biology between those exposed to Group Investigation Strategy and their counterparts taught with the conventional method?

- What is the difference between male and female students' academic achievement in Biology when exposed to Group Investigation Strategy?

\section{Hypotheses}

The following null hypotheses were formulated to guide the study.

- $\mathrm{HO}_{1}$ : There is no significant difference in students' academic achievement level in Biology between those exposed to Group Investigation Strategy and their counterparts taught with the conventional method.

- $\mathrm{HO}_{2}$ : There is no significant difference in the academic achievement of male and female students taught Biology concepts using Group Investigation Strategy.

\section{Methodology}

The design of the study was quasi experimental using a pre-test and post-test control group approach. This design was chosen in order to ensure thorough manipulation of the variables in the study. As an experimental study, the samples for the study were grouped into experimental and the control groups. The experimental group was taught biology concepts using group investigation strategy while the control group was taught the same biology concept using the conventional method. Intact classes were used in order to avoid distortion on the normal class settings and the school timetables.

The population of the study consisted of all the twenty-six thousand three hundred and thirty-eight $(26,238)$ SSII students categorized into male $(13,268)$ and female $(12,970)$ in the six Area Council in FCT-Abuja (Computer/ Statistics Unit SEB, 2018). The reason for the choice of this class was that SSII students were not new to biology and as such would have acquired the basic pre-requisite knowledge in the subject. Also, at this level they are not likely to face any imminent external examination. But the targeted population was 2,147 SSI biology students in the five (5) public Senior Secondary Schools in Kwali Educational Zone categorized into male and female.

Ninety (90) SSII biology students formed the sample for this study. Multi-stage sampling technique was used in selecting the sample. This sampling technique was chosen because it helps the researcher to sample the students across the five (5) schools in Kwali Educational Zone in FCT-Abuja. Details of the sampling procedure are given below:

At the first stage, simple random sampling technique was used to select one Educational Zone (Kwali Educational Zone) out of the six (6) Educational Zone in FCT, Abuja from which two senior secondary schools were selected. The reason for the choice of simple random sampling technique is to give each school equal chance of being selected in the study. In the second stage, simple random sampling technique was also used to select one intact class of Biology students in SSII from each sampled schools in Kwali Educational Zone, making a total of 90 students (male 47 and female 43) which formed the sample size. Finally, one school was randomly assigned experimental group while the other school as control group using balloting. Treatment was assigned to the experimental group. Experimental group was taught using Group Investigation Strategy while the control group was taught using the conventional method. The sampled schools and students are shown in Table 1. 


\begin{tabular}{|c|c|c|c|c|c|}
\hline S/ No. & Schools & Groups & \multicolumn{2}{|c|}{ Sample } & Total \\
\hline & & & Male & Female & \\
\hline 1 & GSS Kwali & Experimental & 26 & 20 & 46 \\
\hline 2 & GSS Dangara & Control & 21 & 23 & 44 \\
\hline & Total & & 47 & 43 & 90 \\
\hline
\end{tabular}

Table 1: Sampled Schools and the Number of SS II Biology

Students selected in Kwali Educational Zone

Source: Field, 2018

The instruments used for this study is an achievement test designed on Biology concept known as Biology Achievement Test (BAT) and a lesson plan.

Biology Achievement Test (BAT) was used as a pre-test and post-test in the study. It consisted of two sections: Section A and Section B. Section A entails the general information of the students while Section B entails the Biology Achievement Test (BAT) questions. The Biology Achievement Test (BAT) consisted of Thirty (30) items multiple choice objective tests with four options A, B, C and D which have been developed by the researcher from the selected topics: digestive system, transport system, respiratory system, excretory system, nutrient cycling, decomposition in nature, ecological management and pollution. This was taught to the students for duration of ten weeks. The guidelines for setting the questions were that of West African Examination Councils (WAEC) and National Examination Council (NECO) syllabi. The questions were selected to cover both theoretical and practical knowledge; so as to determine the effects of group investigation strategy on students' achievements.

\section{Validation of Instruments}

Biology Achievement Test (BAT) was subjected to scrutiny by three experts in the subject area and was content validated using table of specification and face validated by the following: -

- The supervisor and one senior lecturer in the Department of Science and Environmental Education, University of Abuja.

- Two Biology teachers from secondary schools in FCT-Abuja.

The comments and recommendations of the experts had helped in modifying and selection of the test items for the study.

A pilot test involving forty-five (45) senior secondary II biology students (22 males and 23 females) was conducted with the aim to determine the clarity of the test items and how they were understood by the respondents as well as to determine the reliability of the instrument. The school used for the pilot test was Government Secondary School Hajj Camp Gwagwalada Educational Zone, FCT, Abuja which was not intended to be part of the study. Kuder Richardson formula 21 (K-R 21) was used to calculate the internal consistency of the BAT. This method of estimating the internal consistency reliability of an instrument is appropriate for dichotomously scored items such as the BAT which is a multiple choice objective test with right and wrong answers and is easier to use. The outcomes of the pilot test warranted modifications in the test item (BAT). The reliability coefficient of BAT was calculated to be 0.87 . Thus BAT was considered to be reliable enough for data collection in this study.

The data were collected processed and analysed using percentage, frequency count, means and standard deviation and provide answers to the research questions while t-test was used as an instrument to test the hypotheses at 0.05 level of significance as the means of two variables were being compared.

\section{Result and Discussions}

The data obtained from the study have been analysed and presented using mean, standard deviation and t-test statistical analysis.

The characteristics of the subjects that constitute the sample in respect of groups and gender were presented in Table 2.

\begin{tabular}{|c|c|c|c|c|}
\hline Gender & $\begin{array}{c}\text { No. of Students in the } \\
\text { Experimental Group }\end{array}$ & Percentage & $\begin{array}{c}\text { No. of Students in } \\
\text { No. of Students in }\end{array}$ & Percentage \\
\hline Male & 26 & 57.0 & 21 & 48.0 \\
Female & 20 & 43.0 & 23 & 52.0 \\
Total & 46 & 100 & 44 & 100 \\
\hline
\end{tabular}

Table 2: Distribution of Experimental \& Control Group According to Gender

Table 2 indicates the distribution of students who were exposed to experimental and control group according to gender. A break down reveals that of the forty-six students, twenty-six students representing $57.0 \%$ were male students in the experimental group while twenty students representing 43.0\% constituted their female counterparts. Also, a break down reveals that of the forty-four students, twenty-one students representing $48.0 \%$ were male students in the control group while twenty-three students representing $52.0 \%$ constituted their female counterparts. It then means that male students were in the majority in the experimental group while female students were in the majority in the control group. 


\subsection{Research Question One}

What is the difference in the mean achievement scores of Biology students using Group Investigation Strategy and the conventional method? To answer this research question, frequency count, mean and standard deviation were used and the results set out on Table 3 .

\begin{tabular}{|c|c|c|c|c|c|}
\hline Groups & \multirow{2}{*}{ No. of Students } & \multicolumn{2}{|c|}{ Mean Scores } & Standard & Mean Gain \\
\cline { 3 - 4 } & & Peviation & \\
\hline $\begin{array}{c}\text { Group Investigation } \\
\text { Strategy }\end{array}$ & 46 & 14.20 & 27.16 & 9.52 & 12.96 \\
\hline Conventional Method & 44 & 13.96 & 15.05 & 10.12 & 1.05 \\
\hline Mean Difference & & 0.24 & 12.11 & & 11.91 \\
\hline Total & 90 & & & & \\
\hline
\end{tabular}

Table 3: Mean and Standard Deviation for Group

Investigation and Conventional Groups.

From table 3, it has been shown that the mean gain of the students taught Biology using Group Investigation Strategy was 12.96 and those taught using Conventional method was 1.05. This means that the overall mean difference between the groups was 11.91 and these favoured students taught using Group Investigation Strategy (GIS). In essence, the mean achievement scores of students who were taught Biology using Group Investigation Strategy was higher than those taught using Conventional Method with a mean gain of 11.91 which favoured the experimental group.

\subsection{Research Question Two}

What is the difference between male and female students' academic achievement in Biology when exposed to Group Investigation Strategy? To answer this research question, frequency count, mean and standard deviation were used and the results set out on Table 4.

\begin{tabular}{|c|c|c|c|c|c|}
\hline \multirow{2}{*}{ Gender } & \multirow{2}{*}{ No. of Students } & \multicolumn{2}{|c|}{ Mean Scores } & \multirow{2}{*}{ Standard Deviation } & \multirow{2}{*}{ Mean Gain } \\
\cline { 3 - 4 } & & Pre-test & Post-test & & \\
\hline Male & 26 & 14.50 & 26.14 & 9.50 & 11.64 \\
\hline Female & 20 & 13.94 & 25.91 & 10.01 & 11.97 \\
\hline Mean Difference & & 0.56 & 0.23 & & $\mathbf{0 . 3 3}$ \\
\hline Total & 46 & & & & \\
\hline
\end{tabular}

Table 4: Mean and Standard Deviation on Achievement for Male And

Female Students Exposed To Group Investigation Strategy (GIS)

Table 4 shows the means and standard deviation in respect of the gender. The mean gain of the male students taught Biology using Group Investigation Strategy was 11.64 and their female counterparts who were taught using the same strategy in the experimental group was 11.97. The overall mean difference between the groups was 0.33 . It then implies that the mean achievement scores of male and female students taught Biology using Group Investigation Strategy were almost the same having a low difference in value.

\section{Testing of Hypotheses}

9.1. Null Hypothesis One

- $\mathrm{HO}_{1}$ : There is no significant difference in students' academic achievement level in Biology between those exposed to Group Investigation Strategy and their counterparts taught with the Conventional method. To test for this hypothesis, t-test statistic was used and the results presented in Table 5.

\begin{tabular}{|c|c|c|c|c|c|c|c|}
\hline Groups & $\mathbf{N}$ & $\mathbf{X}$ & SD & $\mathbf{t}$ - value & $\mathbf{d f}$ & $\mathbf{P}$ & Decision \\
\hline Experimental & 46 & 27.16 & 9.52 & 8.27 & 88 & 0.000 & significant \\
\hline Control & 44 & 15.05 & 10.12 & & & & \\
\hline
\end{tabular}

Table 5: t-test Result in Respect Of Mean Achievement Scores between the

Experimental and Control Groups

$\mathrm{P}>0.05$ Significant

Result in Table 5, showed that, the calculated t-test value was 8.27, $\mathrm{df}$ was 88 and the p value was 0.000 . This indicates it is significant. Based on the analysis, the hypothesis was rejected. In other words, respondents from both groups differed significantly in their mean achievement scores which favoured the experimental group who were taught using the Group Investigation Strategy. 
- $\mathrm{HO}_{2}$ : There is no significant difference in the academic achievement of male and female students taught Biology concepts using Group Investigation Strategy.To test for this hypothesis, t-test statistic was used and the results presented in Table 6.

\begin{tabular}{|c|c|c|c|c|c|c|c|}
\hline Groups & $\mathbf{N}$ & $\mathbf{X}$ & SD & t - value & $\mathbf{d f}$ & $\mathbf{P}$ & Decision \\
\hline Male & 46 & 26.14 & 9.50 & 0.11 & 44 & 0.622 & $\begin{array}{c}\text { Not } \\
\text { significant }\end{array}$ \\
\hline Female & 44 & 25.91 & 10.01 & & & & \\
\hline
\end{tabular}

Result in Table 6, showed that, the calculated t-test value was 0.11 , df was 44 and the p value was 0.622 . This indicates it is not significant. Based on the analysis, the hypothesis was retained. In other words, respondents from both groups did not differ significantly in their mean achievement scores.

\section{Discussion of Findings}

The data presented in Table 3 provide answer to question one. From the result, it has been shown that the mean gain of the students taught Biology using Group Investigation Strategy was 12.96 and their counterparts taught using Conventional method was 1.05. The overall mean difference between the groups was 11.91 and these favoured students taught using Group Investigation Strategy (GIS). In essence, the mean achievement scores of students who were taught Biology using Group Investigation Strategy was higher than those taught using Conventional Method with a mean gain of 11.91 which favoured the experimental group.

The result of t-test as reported in Table 5 showed that, the calculated t-test value was 8.27 , $\mathrm{df}$ was 88 and the pvalue was 0.000 . This indicates it is significant. Based on the analysis, the hypothesis was rejected. In other words, respondents from both groups differed significantly in their mean achievement scores which favoured the experimental group who were taught using the Group Investigation Strategy. The finding confirms those of Ogundiwin, Asaaju, Adegoke and Ojo (2015) who in their study found that the exposure of the learners to Group Investigative Laboratory strategies have been found to positively affects the enhancement of students' achievement in Biology. The findings also lend support to those of Shachar and Sharan's (1994), Parchment (2009), Mayasari (2012), Nneka (2015), Selviana and David (2017) who found significant difference in favour of the experimental group. Similarly, research conducted by Johnson \& Johnson (2000), Gillies (2004), Sharan \& Tan (2013) showed that GIS increases student involvement, improves academic achievement and interest in learning. On the contrary, Tan, Lee's and Sharans (2007) found in their study that GI was not effective than the whole-class method.

The reason for the significant difference between the mean achievement scores of the two groups was because GIS made students to cooperate socially and motivates them to interact with one another thereby giving them the opportunity of engaging in the learning activities.

The data presented in Table 4 provide answer to question two. Finding shows that the mean gain of the male students taught Biology using Group Investigation Strategy was 11.64 and their female counterparts who were taught using the same strategy in the experimental group was 11.97. The overall mean difference between the groups was 0.33 . It then implies that the mean achievement scores of male and female students taught Biology using Group Investigation Strategy were almost the same having a low difference in value.

The result of $t$-test as reported in Table 6 showed that the calculated t-test value was 0.11 , $\mathrm{df}$ was 44 and the $\mathrm{p}$ value was 0.622 . This indicates it is not significant. Based on the analysis, the hypothesis was retained. In other words, respondents from both groups did not differ significantly in their mean achievement scores.

The findings are supported by Abdu-Raheem (2012), who observed that male and female student's achieved equally in English language. Males achieved better than females in mathematics, science and social science while females also did better than males in Arts except in Yoruba. On the other hand, the study findings contradict the findings of Okoro (2011) who found that male students' achievement and interest score were significantly higher than that of their female counterpart expose to three (3) interaction patterns (cooperative, competitive and individualistic patterns of learning).

The reason for the non-significant difference in the mean achievement scores of male and female students exposed to Group Investigation Strategy was because both male and female students were exposed to the same strategy and both participated actively in the GIS activities in groups as they worked together.

\section{Conclusion}

The study was informed by the need to improve the academic achievement of secondary school students in the subject Biology which deteriorated over the years. The aim to proffer solution to the consistently poor academic performance in Biology has led to the conception of this study which investigated the effects of Group Investigation Strategy on secondary school student's academic achievement in Biology concept in Kwali Educational Zone of FCT-Abuja.

The researcher however, concluded based on the analysis of the results in this study, that the use of Group Investigation Strategy enhances the academic achievement of students in Biology than the conventional method. With GIS, students learnt better about Biology, carried out their responsibilities and made effort to achieve a stated objective. It can be deduced that GIS enhanced the achievement, cooperation and interaction, curiosity and increases retention of learnt concept than conventional method and hence gender friendly. 


\section{Recommendations}

Based on the findings in this study the following recommendations were made:

- Since the use of Group Investigation Strategy has been established to improve student's academic achievement in Biology concepts in secondary schools, teachers should be encouraged to incorporate the GIS into their methods of teaching.

- Professional bodies like Science Teachers Association of Nigeria (STAN) in collaboration with the Nigeria Educational Research and Development Centre (NERDC), Federal Ministry of Education and school proprietors should organize seminars, workshops and conferences on the knowledge of Group Investigation Strategy for science teachers at federal and state levels. If this training is done on regular basis the science teachers will be proficient in the use of innovative strategy like Group Investigation Strategy.

\section{References}

i. Abdu-Raheem, B.O. (2012). The influence of gender on secondary school students' academic performance in south-west, Nigeria. Journal of Social Science, 31 (1), 93 - 98.

ii. Ahmed, M.A. \&Abimbola, I.O. (2011). Influence of teaching experience and school location on biology teachers' rating of the difficult levels of nutrition concepts in Ilorin, Nigeria. Journal of Science, Technology, Mathematics and Education (JOSTMED) , 7(2), 52-61.

iii. Betiku, O. F. (2001). Differential performance of newly introduced topics in senior secondary school mathematics for teacher education. A Journal of the Association of Teacher Educators in Nigeria. 2 (2); 117-112

iv. Federal Republic of Nigeria (2004). National policy on education, Lagos: NERDC Publishers.

v. Gillies, R. (2004). The effects of cooperative learning on junior high school students during small group learning. Learning and instruction, 14, 197-213.

vi. Johnson, D. W., \& Johnson, F. P. (2000). Joining together: Group theory and group skills. (7 ed.) Boston, MA: Allyn and Bacon.

vii. Kagan, S., and M. Kagan, M., (2009). Cooperative learning. Kagan Publishing LTD. California.

viii. Kareem, L.O. (2003). Effects of audio-graphic self-instructional packages on senior secondary school students' performance in biology in ilorin, Nigeria. Unpublished Ph. D thesis of the University of Ilorin, Ilorin.

ix. Leghara, B.N and Mba, C.N. (2010). Sourcing and cost effective use of fund for science and technology education in economic crisis situation.

x. Mayasari, R., (2012). The use of group investigation to improve students' ability in writing skill on analytical exposition text. Encounter, 3(2), 137-154.

xi. Nneka, R, N. (2015). Effect of cooperative learning instructional strategy on senior secondary School student's achievement in biology in Anambra State, Nigeria.International Journal for Cross-Disciplinary Subjects in Education (IJCDSE), Special Issue Vol. (5) I (1).

xii. O'Bannon, B. (2002). Planning for instruction (instructional method). Retrieved on 4th April, 2017 at http:/ / www.feutked/ rbonannon/ in/ strategies/ htm

xiii. Ogundiwin, O.A., Asaaju, O. A., Adegoke, A.L., \& Ojo, A.T. (2015). Effect of group investigative laboratory strategies on students' achievement in biology. Pyrex Journal of Research in Environmental Studies Vol. 2 (4) pp. 035-041.

xiv. Okoro, A. U. (2011). Effect of interaction patterns on achievement and interest in biology among secondary school in enugu state Nigeria. Unpublished MEd Project, University of Nigeria, Nsukka.

xv. Olatoye, R. A \& Adekoya, Y. M. (2009). Effect of four teaching strategies on senior secondary school students' achievement in an aspect of agricultural science. African Journal of Educational Studies in Mathematics and Science. 7,1-16.

xvi. Orji, A. B. C. (2010). The use of computer-assisted instruction in science lesson outcome, Journal of Economic Education, 38 (3) , 259-277

xvii. Orji A.B.C and Ebele F.U. (2011). Effect of thematic instructional strategy on the performance of male and female students in Nigeria secondary schools. International Journal of Science Education, Science, Mathematics and Environmental Studies (JESMES) Vol.3 No1.

xviii. Parchment, G., L. (2009). A Study comparing cooperative learning methods: jigsaw \& group investigation. Mathematical and Computing Sciences Masters. P (25). Fisher Digital Publications.

xix. Sharan, Y., \& Tan, I. G. C. (2013). The group investigation approach to cooperative learning. The International Handbook of Collaborative Learning, 351.

xx. Shachar H. \& Sharan S., (1994). Cooperative learning in the heterogeneous Israeli classroom, International Journal of Educational Research, 23(3), 283-292.

xxi. Selviana N., \& David, B. M. (2017).Developing students' research proposal design through group investigation method. IOSR Journal of Research \& Method in Education (IOSR-JRME). Vol (7), I(1), Ver. III.

xxii. Tan, I.G.C., Lee, C.K.E. \& Sharan, S. (2007). Group investigation effects on achievement, motivation and perceptions of students in Singapore. The Journal of Educational Research, 100 (3), 142-154.

xxiii. Udofia, T.M (2010). Science, technology and mathematics education: The panacea for economic meltdown in Nigeria. 51st STAN Annual Conference Proceeding.

xxiv. Umar, A. A. (2011). Effects of biology practical activities on students' process skill acquisition in minna, Niger State, Nigeria. Journal of Science, Technology, Mathematics and Education (JOSTMED), 7(118-126).

xxv. West African Examinations Council (WAEC), (2010-2016). Chief examiners' reports. Lagos: WAEC. 